\title{
STATUS HIDRASI SETELAH TES KETAHANAN FISIK MAHASISWA JURUSAN TARI USIA 19 - 22 TAHUN (STUDI KASUS DI UNIVERSITAS NEGERI SEMARANG)
}

\author{
Anjarsari Retno Utami, Nurmasari Widyastuti ${ }^{*}$ \\ Program Studi Ilmu Gizi Fakultas Kedokteran Universitas Diponegoro \\ Jl.Dr.Sutomo No.18, Semarang, Telp (024) 8453708, Email : gizifk@undip.ac.id
}

\begin{abstract}
Background :Dancing included in the category of strenuous physical activity. The Dancers must have good physical endurance to support performance in dancing and reduce the incidence of injuries in dance. At the time of performing exercises the body needs more fluid as a result of excessive secretion of fluid through perspiration and breathing is not matched by adequate fluid intake if the deficiency will potentially become dehydrated. Dehydration can affect fatigue in dancer.

Objective : This research intends to description between hydration status after physical endurance test a dance female student.

Methods: Analyze discription which involving 53 student majoring in dance (aged 19-22 years) in Semarang State University. Subjects selected by simple random sampling. The data which collected include the characteristics of the subject, fluid intake, physical endurance tests, physical activity data, hydration status after Harvard Step Test. Fluid intake was using food recall. physical activity data were obtained using International Physical Activity Questionnaire (IPAQ) form, tests of physical endurance measured by the value of VO2max and the status of the hydration after training with the examination of urine specific gravity.

Results : Mean fluid intake on before, during, and after Harvard Step Test $(4.2827 \pm 208.17 \mathrm{ml}, 3.4454 \pm 157.1 \mathrm{ml}$, and $3.817 \pm 188.00 \mathrm{ml})$ is still less than the requirement $(400-2000 \mathrm{ml})$. Subjects suffered dehydration, which consists of were 56,6\% suffered minimum of dehydration and 43,4\% suffered significant dehydration. Subjects it has the value of vo2max that is less (62.3\%), good (9.4\%). fluid intake all dance female student still less than needed so dehydrated and have low physical endurance

Conclusion : fluid intake all dance female student still less than needed so dehydrated and have low physical endurance
\end{abstract}

keywords : hydration status, physical endurance, female students dance

\begin{abstract}
ABSTRAK
Latar Belakang : Menari termasuk dalam kategori aktivitas fisik yang berat. Penari harus mempunyai ketahanan fisik yang baik untuk menunjang performa dalam menari dan mengurangi kejadian cedera tari Pada saat melakukan latihan tubuh membutuhkan cairan yang lebih banyak sebagai akibat dari pengeluaran cairan yang berlebihan melalui keringat dan pernafasan tidak diimbangi dengan konsumsi cairan yang cukup jika kekurangan akan berpotensi mengalami dehidrasi. Dehidrasi dapat mempengaruhi kelelahan pada penari.

Tujuan : Penelitian ini bertujuan untuk menggambarkan status hidrasi setelah tes ketahanan fisik pada mahasisiwi jurusan tari

Metode : Peneliti menggunakan deskriptif analitis yang melibatkan 53 mahasiswi jurusan tari (usia 19-22 tahun) di Universitas Negeri Semarang. Subjek dipilih dengan simple random sampling. Data yang dikumpulkan meliputi karakteristik subjek, konsumsi cairan, tes ketahanan fisik, data aktifitas fisik, status hidrasi setelah tes harvard. Konsumsi cairan diukur dengan menggunakan food recall, data aktivitas fisik didapatkan melalui formulir International Physical Activity Questionnaire (IPAQ), tes ketahanan fisik diukur dengan nilai VO2max dan status hidrasi setelah tes harvard diketahui dengan pemeriksaan berat jenis urin.

Hasil : Rerata konsumsi cairan pada sebelum, selama dan sesudah melakukan test harvard $(4.2827 \pm 208.17 \mathrm{ml}$, $3.4454 \pm 157.1 \mathrm{ml}$, dan 3.817 $\pm 188.00 \mathrm{ml})$ masih kurang dari kebutuhan $(400-2000 \mathrm{ml})$. Semua subjek mengalami dehidrasi, yang terdiri dari 56,6\% mengalami minimal dehydration dan 43,4\% mengalami significant dehydration. Subjek mempunyai nilai VO2max yang rendah (62.3\%), dan baik (9.4\%).
\end{abstract}

Simpulan Sebagian mahasisiwi jurusan tari mengalami dehidrasi dan mempunyai nilai vo2max yang rendah Kata Kunci : Status Hidrasi, Ketahanan Fisik, mahasiswi tari

\section{PENDAHULUAN}

Tari adalah sebuah ungkapan gerak emosional dengan pola gerak tubuh yang ekspresif dan komunikatif. Unsur yang paling mendasar dalam tari adalah gerak ${ }^{1}$. Gerakan tersebut meliputi kekuatan, ketahanan, keseimbangan, kecepatan, ketepatan kelenturan, kelincahan dan koordinasi gerak tubuh. ${ }^{1,2}$ Salah satu contoh dalam gerak tari yang menggunakan daya tahan dan kekuatan kaki adalah gerak tari pada tari jawa pada gaya surakarta 
pada tungkai, yaitu posisi tanjak. ${ }^{3}$ Pada kondisi ini yang terasa adalah beban tubuh apabila berdiri tegak lurus. Bagi seorang penari akan sadar pentingnya kekuatan tungkai ${ }^{3}$. Latihan seperti melatih keseimbangan, kecepatan, kelenturan membuat penari dituntut untuk latihan aerobik. Dampak dari jadwal dan bentuk latihan tersebut membuat penari mempunyai aktifitas fisik yang berat dan disamakan dengan atlet. ${ }^{4}$ Penari selalu meningkatkan kualitas dengan berlatih berulang-ulang agar dapat tampil maksimal dalam sebuah pertunjukan. Hal ini menuntut penari untuk selalu dalam kondisi yang prima dan mempunyai ketahanan fisik yang baik untuk menunjang performa pada saat pementasan ${ }^{5}$. Beberapa penelitian menunjukkan bahwa latihan ketahanan fisik dapat menyebabkan penari menari lebih baik dan mengurangi kejadian cedera tari. Penelitian di Amerika menunjukan bahwa kejadian cedera ringan ( seperti nyeri otot, kram, luka ringan) dalam berbagai kelompok tari sebesar $74 \%$, dan angka kejadian cedera kronis (cedera musculoskeletal) pada penari professional sebesar $48 \% .{ }^{6}$ Sedangkan penelitian di Swedia menyatakan bahwa prevalensi nyeri musculoskeletal pada penari profesional sebesar $95 \% .{ }^{542}$ Ketahanan fisik dapat dipengaruhi oleh status gizi, dan aktifitas fisik. Faktor lain yang ikut mempengaruhi juga yaitu usia, jenis kelamin, dan genetik. ${ }^{6}$ salah satu metode yang dapat dilakukan untuk mengetahui bagaimana ketahanan fisik seseorang adalah dengan menggunakan Harvard Step up test.

Harvard step up test merupakan tes yang digunakan untuk kemampuan cardio vascular system didalam mengelola $\mathrm{O} 2$ dalam tubuh yang dipergunakan pada waktu kerja berat kontraksi otot yang digunakan pada tes ini otot rangka dan otot jantung. Pada saat melakukan latihan ini tubuh membutuhkan cairan yang lebih banyak sebagai akibat dari pengeluaran cairan yang berlebihan melalui keringat.

Beberapa penelitian menunjukkan bahwa tidak semua penari terhidrasi dengan baik sebelum dan setelah latihan tari dilakukan. Penelitian yang dilakukan di Amerika menunjukan bahwa penari mengalami dehidrasi 1-3\% sebelum menjalani latihan tari kemudian menjadi $6 \%$ selama menjalani latihan tari. Status hidrasi dapat diartikan sebagai keseimbangan cairan dalam tubuh dan merupakan syarat penting untuk menjamin fungsi metabolisme sel tubuh ${ }^{7}$. Penari juga membutuhkan pengaturan hidrasi yang baik. Pengaturan status hidrasi yang baik dapat meningkatkan performa penari ${ }^{8}$. Salah satu unsur gizi yang penting untuk tetap menjaga kondisi optimal dalam performance penari yaitu konsumsi air. Konsumsi cairan yang tidak mencukupi dapat mempengaruhi status hidrasi , kelelahan, dan performa. Penelitian di Amerika juga menyatakan bahwa dari 65 subjek penari, 2.5\% yang mempunyai status hidrasi yang baik dapat mengurangi kelelahan sebanyak 6\%.9 Penari kehilangan rata - rata $3.5 \mathrm{~kg}$ berat badan meskipun menelan 2 liter cairan. ${ }^{10}$ Kehilangan cairan atau dehidrasi dapat mengganggu kinerja dan fungsi mental, serta gangguan konsentrasi dalam melakukan gerakan - gerakan yang membutuhkan daya konsentrasi ${ }^{11,12}$

Berbagai metode dapat digunakan untuk penilaian status hidrasi dalam tubuh, antara lain penurunan berat badan (body mass loss), air tubuh total (total body water), volume darah, perubahan volume plasma, ${ }^{8,12}$ Serta indikator dengan urin melalui berat jenis urin, warna urin, osmolalitas urin, konduktivitas urin. Metode berat jenis urin berkolerasi kuat dengan osmolalitas urin karena berat jenis urin tergantung dari berat molekular dan jumlah partikel dalam urin ${ }^{12}$. Oleh karena itu, sering digunakan metode berat jenis urin dan warna urin untuk penilaian status hidrasi di tingkat masyarakat. ${ }^{8,12}$

Menurut hasil Survey awal yang dilakukan pada 53 mahasiswi jurusan tari Universitas Negeri Semarang menunjukkan 100\% mengalami dehidrasi setelah melakukan latihan tari selama 30 menit hal ini diukur dengan indikator warna urin dengan menggunakan PURI. Mahasiswa jurusan tari Universitas Negeri Semarang mempunyai intensitas melakukan latihan menari sebanyak 5 kali dalam seminggu dengan durasi latihan menari yang cukup lama sekitar 1-4 jam per hari yang meliputi pelatihan olah tubuh meliputi latihan pemanasan, latihan inti (yang terdiri dari latihan keseimbangan, kekuatan, kelenturan), pendinginan, kemudian diikuti dengan latihan menari. Berdasarkan latar belakang di atas, peneliti tertarik mengetahui bagaimanai status hidrasi dengan indikator nilai Berat Jenis Urin (BJU) setelah tes ketahanan fisik

\section{METODE}

Penelitian ini termasuk dalam ruang lingkup keilmuan gizi masyarakat dan dengan menggunakan metode deskriptif analitis. Populasi dalam penelitian ini adalah semua Mahasiswi jurusan tari usia 19-22 tahun di Universitas Negeri Semarang. Besar sampel dalam penelitian ini adalah 53 orang. Subjek diambil dengan cara simple random sampling. Subjek dipilih berdasarkan kriteria inklusi yaitu tercatat sebagai Mahasiswi Tari Universitas Negeri Semarang, bersedia 
mengisi inform consent, tidak demam, tidak mengalami diare, tidak sedang menstruasi, tidak menggunakan obat diuretik

Pengambilan data dilakukan pada bulan Desember 2014. Data yang dikumpulkan dalam penelitian ini adalah karakteristik subjek, data test Harvard step up test, data aktifitas fisik, konsumsi cairan, dan status hidrasi setelah melakukan Harvard step up test. Data karakteristik subjek diperoleh melalui wawancara langsung dengan menggunakan kuesioner meliputi nama dan tanggal lahir dan data antropometri. Data antropometri terdiri dari pengukuran tinggi badan microtoise ketelitian 0,1 cm dengan menggunakan Pengukuran berat badan dilakukan sebelum melakukan tes Harvard step test dengan menggunakan timbangan digital yang mempunyai ketelitian $0,1 \mathrm{~kg} \cdot{ }^{14,15}$ dan pengukuran berat badan menggunakan timbangan injak.

Ketahanan fisik adalah kemampuan seseorang untuk melakukan aktifitas sehari - hari tanpa menimbulkan kelelahan yang berarti dan masih memiliki cadangan energi untuk melakukan aktivitas fisik. Pengukuran dilakukan dengan menggunakan metode Harvard step up test yang bertujuan untuk mengukur daya tahan jantung paru berdasarkan pemulihan nadi setelah step test. pengukuran dilakukan pada pagi hari sebelum melakukan aktivitas sehari - hari dengan menggunakan bangku Harvard/tangga sekitar $20 \mathrm{~cm}$, kemudian gerakan naik turun kaki mengikuti irama metronom yang terpasang pada frekuensi 120 kali per menit atau naik turun 30 kali per menit, abaaba stop dilakukan pada hitungan 5 menit kemudian dicatat denyut nadi subjek dan di hitung menggunakan rumus VO2Max. ${ }^{25}$ Klasifikasi nilai VO2max menurut Harvard step ${ }^{23}$ :

$-<50=$ jelek,

- 50-80 = sedang,

- $>80$ = baik,

Status hidrasi setelah test harvard adalah suatu kondisi yang menggambarkan keseimbangan cairan dalam tubuh penari setelah melakukan test Harvard yang bertujuan untuk mengetahui status hidrasi dan tingkat dehidrasi mahasiswi tari setelah melakukan Harvard step test yang dapat diketahui dengan cara pemeriksaan berat jenis urin (BJU). Metode berat jenis urin (BJU) dipilih karena mudah dilaksanakan, sering digunakan, waktu analisis singkat, ketepatan baik, biaya terjangkau, portabilitas alat baik, dan rendahnya resiko bagi subjek. $^{27}$

Pengambilan sampel urin dilakukan setelah melakukan Harvard step up test dengan menggunakan botol kaca bening. Pemeriksaan BJU dilakukan di laboratorium dengan menggunakan metode reagent strip. ${ }^{9}$ BJU dikategorikan menjadi empat, yaitu well-hydrated apabila nilai BJU $<1.010 \mathrm{~g} / \mathrm{dl}$, minimal dehydration apabila nilai BJU 1.010-1.020 g/dl, significant dehydration apabila nilai BJU 1.021-1.030 $\mathrm{g} / \mathrm{dl}$, dan seriously dehydration apabila nilai $\mathrm{BJU}>1.030 \mathrm{~g} / \mathrm{dl} .^{9,27}$

Konsumsi cairan adalah jumlah total cairan yang masuk dalam tubuh yang berasal dari minuman dan makanan yang diperoleh melalui food recall selama $1 \times 24$ jam. Konsumsi cairan yang diukur dalam penelitian ini adalah konsumsi cairan sehari dan konsumsi cairan pada sebelum, selama, dan setelah Harvard step test. Konsumsi cairan sehari adalah jumlah total cairan yang dikonsumsi baik dari minuman maupun makanan yang diukur 24 jam sebelum latihan selesai.. Konsumsi cairan sebelum Harvard step test adalah jumlah total cairan yang dikonsumsi baik dari minuman maupun makanan yang diukur 4 jam sebelum latihan dimulai. Konsumsi cairan 4 jam sebelum Harvard step test dikatakan cukup jika mengonsumsi cairan minimal 400-600 ml. ${ }^{8,14,15}$ Konsumsi cairan selama Harvard step test adalah jumlah total cairan yang dikonsumsi baik dari minuman maupun makanan yang diukur selama latihan tari dan melakukan Harvard step up test. Konsumsi cairan selama melakukan Harvard step test dikatakan cukup jika mengonsumsi cairan minimal 700-1000 ml. ${ }^{15,17}$ Konsumsi cairan setelah Harvard step test adalah jumlah total cairan yang dikonsumsi baik dari minuman maupun makanan yang diukur 1 jam setelah latihan selesai. Konsumsi cairan setelah Harvard step test dikatakan cukup jika mengonsumsi 500-700 ml. sedangkan konsumsi cairan sehari dikatakan cukup jika mengonsumsi 2700 ml. $^{15}$ Perhitungan jumlah total konsumsi cairan menggunakan rumus pertambahan total cairan dari minuman dan total cairan dari makanan yang dilihat dari DKBM (Daftar Komposisi Bahan Makanan) 2009.

Aktivitas fisik diukur menggunakan International Physical Activity Questionnaire Adolescent (IPAQ) untuk mengetahui besar energi yang dikeluarkan subjek dalam berkegiatan selama 7 hari terakhir dan dihitung menggunakan rumus yang sudah ditentukan dengan satuan METmenit/minggu. Hasil perhitungan dikategorikan menjadi aktivitas ringan (<600METmenit/minggu), aktivitas sedang (600-2999 METmenit/minggu), dan aktivitas berat (>2999 METmenit/minggu). ${ }^{18}$

\section{HASIL PENELITIAN}


Jumlah subjek pada peneltian adalah 53 penari wanita. Usia subjek berkisar 19-22 dengan, rerata IMT $20.43 \pm 2.315 \mathrm{~kg} / \mathrm{m}^{2}$, Aktivitas fisik subjek tergolong berat dengan rerata $3.270 \pm 1630.825 \mathrm{MET}-\mathrm{menit} / \mathrm{minggu}$, nilai vo2max dengan menggunakan test Harvard step up test subjek memiliki rerata $56.52 \pm 8.004$, dan subjek tergolong mengalami dehidrasi dengan rerata nilai BJU subjek $1.02 \pm 0.004 \mathrm{~g} / \mathrm{dl}$. Karakteritik subjek penelitian ditunjukkan pada tabel 1.

Tabel 1. Karakteristik Subjek berdasarkan Usia, Tinggi Badan, IMT dan Berat Jenis Urin

Karakteristik Subjek

Usia

Berat badan

Tinggi badan

Imt

Aktifitas fisik

VO2max

Berat jenis urin $\mathrm{n}=53$

\begin{tabular}{lll}
\hline Minimum & Maximum & Rerata \pm SD
\end{tabular}

19

38.7

145.5

17.06

1038

34.80

1.015

22
66.1
165.6
27.27
8478
76.30
1.030

$19,3 \pm 0,75$

$48,15 \pm 6,116$

$152.88 \pm 4.228$

$20.43 \pm 2.315$

$3.270 \pm 1630.825$

$56.52 \pm 8.004$

$1.02 \pm 0.004$

\section{Ketahanan fisik}

Hasil pengukuran ketahanan fisik subjek menunjukan bahwa $>50 \%$ memiliki ketahanan fisik yang kurang. Responden memiliki ketahanan fisik yang sangat rendah sebanyak $15.1 \%$, rendah sebanyak $62.3 \%$, cukup sebanyak $13.2 \%$, dan baik sebanyak 9.4\%, Distribusi frekuensi kategori nilai Vo2max dapat dilihat pada tabel 2.

Tabel 2. Frekuensi kategori nilai Vo2max

\begin{tabular}{lcc}
\hline Vo2max & Frekuensi (n) & Persentase (\%) \\
\hline Baik & 5 & $9.4 \%$ \\
Cukup & 7 & $13.2 \%$ \\
Rendah & 33 & $62.3 \%$ \\
Sangat rendah & 8 & $15.1 \%$ \\
\hline
\end{tabular}

\section{Aktifitas Fisik}

Hasil pengukuran aktifitas fisik subjek menunjukan bahwa sebagian besar subjek (43.4\%) memiliki aktifitas fisik yang berat dan 30 subjek atau sebesar $56.6 \%$ mempunyai aktifitas fisik sedang Tidak ditemukan subjek dengan aktivitas fisik kategori ringan. Distribusi frekuensi frekuensi aktifitas fisik dapat dilihat pada tabel 3 .

Tabel 3. Distribusi Frekuensi Aktifitas Fisik

\begin{tabular}{lcc}
\hline \multicolumn{1}{c}{ Aktifitas fisik } & Frekuensi (n) & Persentase (\%) \\
\hline Sedang & 30 & 56.6 \\
Berat & 23 & 43.4 \\
\hline Total & 53 & 100 \\
\hline
\end{tabular}

\section{Status Gizi}

Status gizi pada subjek berdasarkan IMT pada penelitian ini beragam. Sebagian besar subjek memiliki status gizi underweight (15.1\%), normal $(69.8 \%)$, overweight $(9.4 \%)$ dan hanya 3 subjek $(5,7 \%)$ dengan status gizi obesitas .

Tabel 4. Distribusi Frekuensi Status Gizi

\begin{tabular}{ccc}
\hline Kategori & Frekuensi (n) & Persentase (\%) \\
\hline underweight & 8 & $15.1 \%$ \\
normal & 37 & $69.8 \%$ \\
overweight & 5 & $9.4 \%$ \\
obesitas & 3 & $5.7 \%$ \\
\hline
\end{tabular}




\section{Konsumsi Cairan}

Konsumsi cairan sehari subjek berkisar antara 876.00-3669.60 ml dengan rerata $1.5859 \pm 563.794$, sedangkan rerata konsumsi cairan subjek sebelum selama dan setelah melakukan test harvard adalah $4.2827 \pm 208.170 \mathrm{ml}$, $3.4454 \pm 157.196 \mathrm{ml}$, dan $3.817 \pm 188.007 \mathrm{ml}$ Konsumsi cairan dapat dilihat pada table 5

Tabel 5. Karakteristik Subjek Berdasarkan Konsumsi Cairan

\begin{tabular}{lrrr}
\hline \multicolumn{1}{c}{ Konsumsi cairan } & \multicolumn{3}{c}{$\mathbf{n = 5 3}$} \\
\cline { 2 - 4 } & $\begin{array}{c}\text { Minimu } \\
\mathbf{m}\end{array}$ & Maximum & Rerata \pm SD \\
Konsumsi cairan sehari & 876.00 & 3669.60 & $1.5859 \pm 563.794$ \\
Konsumsi cairan sebelum Tes Harvard & 120.00 & 1000.00 & $4.2827 \pm 208.170$ \\
Konsumsi cairan selama Tes Harvard & 100.00 & 600.00 & $3.4454 \pm 157.196$ \\
Konsumsi cairan sesudah Tes Harvard & 240.00 & 850.00 & $3.817 \pm 188.007$ \\
& & & \\
\hline
\end{tabular}

Berdasarkan hasil penelitian, hampir semua subjek menunjukan bahwa konsumsi cairan sehari maupun konsumsi cairan periode dalam periode latihan kurang. $94.3 \%$ subjek mengkonsumsi cairan dalam sehari kurang dari kebutuhan seharusnya.
Lebih dari $80 \%$ subjek mengkonsumsi cairan yang kurang pada saat latihan dan setelah latihan. Distribusi frekuensi kategori konsumsi cairan dapat dilihat pada tabel 6 .

Tabel 6. Distribusi Frekuensi Kategori Konsumsi Cairan

\begin{tabular}{|c|c|c|c|c|c|c|}
\hline \multirow{3}{*}{ Konsumsi Cairan } & \multicolumn{4}{|c|}{ Kategori } & \multirow{2}{*}{\multicolumn{2}{|c|}{ Total }} \\
\hline & \multicolumn{2}{|c|}{ Kurang } & \multicolumn{2}{|c|}{ Cukup } & & \\
\hline & $\mathbf{N}$ & $\%$ & $\mathbf{N}$ & $\%$ & $\mathbf{N}$ & $\%$ \\
\hline Konsumsi Cairan Sehari (ml) & 50 & 94,3 & 3 & 5,7 & 53 & 100 \\
\hline Konsumsi Cairan Sebelum tes Harvard(ml) & 43 & 81.1 & 10 & 18.9 & 53 & 100 \\
\hline Konsumsi Cairan Selama tes Harvard (ml) & 53 & 100 & & & 53 & 100 \\
\hline Konsumsi Cairan Setelah tes Harvard (ml) & 42 & 72.4 & 11 & 20.7 & 53 & 100 \\
\hline
\end{tabular}

\section{Status hidrasi}

Hasil pengukuran Nilai Berat Jenis Urin (BJU) menunjukan bahwa semua subjek mengalami dehidrasi (BJU $\geq 1.010 \mathrm{~g} / \mathrm{dl}$ ). $43.4 \%$ mengalami significant dehydration (nilai BJU 1.021-1.030 g/dl) dan sisanya sebesar $56.6 \%$. mengalami minimal dehydration (nilai BJU 1.010-1.020 g/dl). Distribusi frekuensi status hidrasi setelah tes Harvard dapat dilihat pada tabel 7 .

Tabel 7. Distribusi Frekuensi Status Hidrasi Setelah Tes Harvard

\begin{tabular}{lcc}
\hline \multicolumn{1}{c}{ Status Hidrasi } & Frekuensi (n) & Persentase (\%) \\
\hline Minimal dehydration & 30 & 56.6 \\
Significant dehydration & 23 & 43.4 \\
\hline Total & 53 & 100 \\
\hline
\end{tabular}

\section{PEMBAHASAN}

Penelitian ini dilakukan pada mahasiswi tari dengan rentang usia 19-22. Rentang usia tersebut termasuk dalam masa dewasa muda dimana masih terdapat banyak aktifitas yang dijalani termasuk pada mahasiswi jurusan tari ini. Menari yang sebanding dengan olahraga tergolong dalam aktivitas fisik yang berat dilihat dari segi fisik, ketangkasan, dan psikologis. ${ }^{16}$ Menari juga merupakan sebuah latihan yang mensubstitusi aspek atletik dengan komponen artistik dan estetik. ${ }^{2} \mathrm{Hal}$ ini dibuktikan dengan hasil penelitian yang menyatakan sebagian besar aktivitas fisik subjek dalam penelitian ini tergolong berat dengan rerata 3.270 $\pm 1630.825 \mathrm{MET}$-menit/minggu.

\section{Ketahanan Fisik}

Ketahanan fisik dapat diukur dengan menggunakan vo2max. Daya tahan kardiorespirasi sering dihubungkan sebagai aspek penting dalam kebugaran seseorang yang memiliki hal tersebut memiliki resiko penyakit jantung yang rendah dan dapat bertahan melakukan aktifitas fisik dalam waktu yang lama tanpa merasa kelelahan. Dalam hal ini Vo2max merupakan kapasitas maksimum 
seseorang yang menggambarkan kebugaran fisik seseorang. Namun dikarenakan membutuhkan usaha dan kemauan yang besar dari responden., pengukuran vo2max sering dianggap tidak mudah bagi beberapa individu. Oleh karena itu beberapa metode dikembangkan untuk menyediakan metode yang mudah namun valid untuk mengestimasi kebugaran aerobic.

Pada penelitian ini data ketahanan fisik yang didapat dengan menggunakan metode tes Harvard data pengukuran ketahanan fisik subjek menunjukan bahwa $>50 \%$ memiliki kesegaran jasmani yang kurang. Responden memiliki kesegaran jasmani yang sangat rendah sebanyak $15.1 \%$, rendah sebanyak $62.3 \%$, cukup sebanyak $13.2 \%$, dan baik sebanyak $9.4 \%$,

Pada penelitian yang dilakukan oleh indrawagita pada mahasiswi FKM ui dengan menggunakan Harvard step test terdapat lebih banyak responden yang tergolong tidak bugar $(86,7 \%)$ dibandingkan dengan yang bugar $(13,3 \%)$

Selain itu, sebuah penelitian halaskar di india dengan menggunakan metode ergometer step juga didominasi oleh sampel yang memiliki tingkat kebugaran pada kondisi buruk yaitu sebanyak 63,3\% Hal ini dapat disebabkan oleh karakteristik sampel yang berbeda pada laki - laki yang memiliki masa otot lebih dibandingkan dengan wanita sehingga lebih mempunyai daya tahan yang baik dibandingkan dengan wanita dan dengan aktifitas pekerjaan yang tergolong berat. Ketahanan fisik juga dapat dipengaruhi oleh aktifitas fisik. Pada penelitian ini aktifitas fisik subjek yang diukur dengan menggunakan metode IPAQ menunjukan bahwa sebagian besar subjek (43.4\%) memiliki aktifitas fisik yang berat dan 30 subjek atau sebesar $56.6 \%$ mempunyai aktifitas fisik sedang.

Secara teori, dengan meningkatkan aktivitas fisik dengan cara latihan fisik yang baik, benar, terukur, dan teratur dapat meningkatkan ketahanan fisik. ${ }^{28}$ Hasil penelitian yang dilakukan oleh Supriyanto (2013) terhadap siswa ekstrakulikuler bola basket di SMP Negeri 2 Ketapang Kabupaten Sampang menunjukan bahwa beberapa kegiatan fisik seperti latihan lari angkat paha, lompat tepuk, push up dengan pola circuit training dapat memberikan peningkatan kesegaran jasmani pada siswa ekstrakulikuler bola basket. Oleh karena itu, ketahanan fisik siswa yang diperoleh pada saat penelitian umumnya tergolong ketahanan fisik baik disebabkan adanya pola latihan fisik yang selama ini dijalankan dalam pendidikan. ${ }^{32}$

Baik tidaknya ketahanan fisik seorang penari tidak diperoleh hanya dengan melakukan aktivitas fisik dalam sehari atau dua hari saja seperti pada penelitian yang dilakukan. Tetapi, ketahanan fisik tersebut diperoleh dari latihan-latihan fisik yang sudah dilakukan secara teratur sejak awal melakukan pendidikan tari hingga diakhir pendidikan nantinya.

\section{Status Gizi}

Penari selalu memperhatikan bentuk tubuh mereka agar dapat lebih memaksimalkan pertunjukan. Hal ini dapat dibuktikan dengan hasil penelitian yang menujukan Status gizi pada subjek berdasarkan IMT beragam. Sebagian besar subjek memiliki status gizi underweight (15.1\%), normal $(69.8 \%)$ overweight $(9.4 \%)$ dan hanya 3 subjek $(5,7 \%)$ dengan status gizi obesitas.

Komposisi tubuh yang optimal pada penari berperan penting untuk mencapai kebutuhan fisiologis dari tubuh yang sehat dan estetika bentuk tubuh sehingga dapat melakukan pola gerak yang maksimal saat performa. Rata-rata penari memiliki bentuk tubuh yang ramping dengan persentase lemak tubuh yang tergolong rendah berkisar 13,8$22,1 \%$ dari berat badan.

Penelitian mengenai citra tubuh pada remaja putri yang duduk dibangku SMA, bahwa remaja putri pada umumnya yang berusia 17-22 tahun mulai memfokuskan diri dengan penampilan mereka dan sangat khawatir bila berat badan mereka tidak ideal dengan tinggi badan mereka, penelitian tersebut juga menunjukkan bahwa sebagian besar remaja putrid $70-85 \%$ mempunyai pandangan mengenai body image negatif (ketidakpuasan terhadap bentuk dan ukuran tubuh), hanya sekitar $30-50 \%$ yang mempunyai pandangan mengenai body image positif (kepuasaan terhadap bentuk dan ukuran badan) pada Perempuan (khususnya remaja putri) cenderung lebih memperhatikkan bentuk tubuh dan menurut presepsi mereka bentuk tubuh yang baik adalah tubuh yang kurus dan langsing. Hal ini semakin dipengaruh dari tuntutan pekerjaan terutama bagi seorang yang berprofesi sebagai penari yang harus memaksimalkan gerakan pada saat pementasan. ${ }^{29}$ Bentuk tubuh yang lebih ramping dianggap dapat mempermudah dalam bergerak

Pada penelitian ini 3 subjek (5,7\%) dengan status gizi obesitas. Dalam penelitian crosssectional, prevalensi kelebihan berat badan selalu dilaporkan. Tingkat ketahanan fisik selalu lebih rendah pada responden obesitas dikarenakan mereka yang mempunyai berat badan berlebih lebih sulit bergerak dan kecenderungan memiliki aktifitas fisik yang kurang kemudian mengakibatkan peningkatan cadangan lemak dalam tubuh. Indeks massa tubuh hanya menggambarkan berat badan secara kseluruhan, termasuk lemak tubuh. Massa 
bebas lemak terdiri dari otot, tulang, air dan semua yang tidakterbentuk dr lemak. Jaringan lemak tidak menggunakan oksigen semakin tinggi lemak tubuh semakin mengurangi energi oksidatif sehingga massa bebas lemak mempengaruhi nilai vo2max seseorang.

Penelitian sebelumnya tentang kebugaran dengan perhitungan VO2max yang dilakukan oleh Pribis di Andrew University pada 5101 mahasiswa. Dalam penelitian tersebut dinyatakan bahwa tren linier imt dari tahun 1996- 2008 signifikan baik pada perempuan maupun laki - laki dengan $\mathrm{p}$ value keduannya $<0,001$. Dengan peningkatan IMT, maka daya tahan fisik (Vo2max) semakin menurun. ${ }^{32}$

Penelitian lain yang dilakukan oleh prista, et al (2003) di mozambik oleh 2316 sampel perempuan dengan dengan metode tes bangku selama 3 menit juga menyatakan bahwa kelompok dengan status gizi lebih tergolong paling buruk hampir dalam tes ketahanan fisik. ${ }^{33}$

\section{Konsumsi Cairan}

Konsumsi cairan yang diasup oleh subjek masih dikatakan kurang karena ini terbukti $>80 \%$ subjek hanya mengasup cairan sebanyak 300-500 L sebelum latihan sedangkan rekomendasi asupan yang dianjurkan 400 - $600 \mathrm{ml}$.konsumsi cairan sehari yang diasup sebagian subjek juga mengalami defisit cairan ini karena subjek hanya mengasup cairan sekitar 400-2000ml cairan sedangkan rekomendasi untuk asupan cairan sehari $\pm 2700 \mathrm{ml}^{10,12}$ Konsumsi cairan yang kurang dapat terjadi karena kurangnya pengaturan konsumsi cairan pada saat periode tes Harvard yaitu sebelum, selama dan setelah melakukan tes harvard. Konsumsi cairan yang tepat sebelum, selama dan setelah latihan diperlukan untuk menjaga status hidrasi dan menunjang performa. Namun, kebutuhan cairan akan semakin meningkat apabila aktifitas fisik semakin tinggi dan suhu semakin panas.

Pada Penelitian ini menunjukan konsumsi cairan sebelum latihan kurang dari kebutuhan seharusnya. Hal ini karena pengukuran konsumsi cairan sebelum latihan dilakukan 4 jam sebelum tes Harvard dimulai dan biasanya mahasiswi tari tersebut masih belum banyak melakukan aktifitas sehingga penari seharusnya mempunyai banyak kesempatan untuk mengakses makanan dan minuman. Selama latihan, ditemukan banyak penari yang konsumsi cairannya kurang. Penari yang juga disamakan dengan atlet karena aktifitasnya yang tinggi maka dari itu penari dianjurkan untuk mengonsumsi cairan 200-250 ml setiap 15 menit tetapi dalam penelitian ini waktu konsumsi cairan subjek terbatas karena hanya mengonsumsi makanan atau minuman saat istirahat saja. Hampir semua konsumsi cairan subjek setelah latihan adalah kurang. Hal ini sama menunjukkan bahwa penari tidak memaksimalkan kesempatan untuk mengakses minuman. Padahal penari dapat dengan mudah mengakses makanan atau minuman yang tersedia di kantin.

\section{Status Hidrasi}

Hidrasi yang diartikan sebagai keseimbangan cairan dalam tubuh dan merupakan syarat penting untuk menjamin fungsi metabolisme sel tubuh Hasil pengukuran status hidrasi pada penelitian ini yang diukur dengan Nilai Berat Jenis Urin (BJU) menunjukan bahwa semua subjek mengalami dehidrasi (BJU $\geq 1.010 \mathrm{~g} / \mathrm{dl}$ ). $43.4 \%$ mengalami significant dehydration (nilai BJU 1.021-1.030 g/dl) dan sisanya sebesar 56.6\%. mengalami minimal dehydration (nilai BJU 1.010$1.020 \mathrm{~g} / \mathrm{dl}$ ). Penelitian di Yunani pada penari balet remaja menunjukkan bahwa 94 dari 107 penari mengalami dehidrasi sebelum latihan dengan BJU $\geq 1.020 \mathrm{~g} / \mathrm{dl}$. Pada penelitian ini subjek mengalami dehidrasi dikarenakan subjek kurang dapat mengakses minuman dengan baik sehingga konsumsi cairan kurang dari kebutuhan seharusnya. Hasil tersebut sesuai dengan teori. Saat kekurangan asupan cairan maupun kehilangan cairan secara berlebih, di dalam darah terjadi peningkatan osmolalitas sehingga darah menjadi hipertonik. Osmoreseptor di dalam hipotalamus mendeteksi peningkatan osmolalitas darah sehingga menstimulasi kelenjar ptituari untuk mensekresi antidiuretic hormon (ADH). ADH menstimulasi ginjal untuk meningkatkan absorbsi air. Hal ini menyebabkan penurunan jumlah keluaran urin dan peningkatan konsentrasi urin. ${ }^{11,13,14}$ Saat yang sama, osmoreseptor juga menstimulasi rasa haus supaya mengonsumsi cairan dan digunakan untuk mengembalikan keseimbangan cairan dalam tubuh. Saat latihan menari, penari sebaiknya tidak bergantung pada rasa haus tetapi melakukan pengaturan minum yang tepat untuk menjaga keseimbangan cairan tubuh dan performa penari. Penelitian di Amerika juga menyatakan bahwa dari 65 subjek sebagai penari $2.5 \%$ yang mempunyai kadar hidrasi yang baik dapat mengurangi kelelahan sebanyak $6 \% .^{25}$

Faktor lain yang dapat mempengaruhi status hidrasi adalah suhu lingkungan. Tubuh dapat kehilangan cairan dalam jumlah yang sama saat suhu lingkungan panas ataupun dingin karena energi yang terpakai untuk menjaga panas tubuh dan penggunaan pakaian tertentu. Latihan dengan intensitas tinggi selama 60 menit pada suhu lingkungan yang panas $\left(31-32{ }^{\circ} \mathrm{C}\right)$ dapat 
meningkatkan produksi keringat dan kehilangan cairan sebanyak $2 \%$ dari berat tubuh. ${ }^{12}$ Pada suhu dingin dapat membuat seseorang kehilangan cairan karena banyak buang air kecil dan kulit menjadi kering karena kelembaban kulit menurun. Pada suhu dingin, kehilangan cairan banyak melalui pernafasan. Orang cenderung lebih mudah dehidrasi pada suhu dingin karena pada suhu dingin orang sering merasa tidak haus dan kurang minum. Oleh karena itu, perlu dilakukan pengaturan konsumsi cairan baik pada suhu panas maupun dingin untuk mencegah terjadinya dehidrasi

\section{SIMPULAN}

Konsumsi cairan pada sebelum, selama, dan sesudah tes harvard masih kurang dari kebutuhan seharusnya sehingga semua subjek mengalami dehidrasi. Aktifitas fisik yang tinggi dapat berkontribusi ke status hidrasi mahasiswi tari sehingga mempengaruhi status hidrasi menjadi lebih tinggi. Sebagian besar subjek juga mempunyai nilai Vo2max yang rendah.

\section{SARAN}

Perlu adanya peningkatan konsumsi cairan sesuai dengan kebutuhan (1000-2000 ml) saat latihan untuk mencegah terjadinya dehidrasi. Hal ini dapat dilakukan dengan membiasakan diri membawa botol minum sendiri saat latihan. Selain itu, juga diperlukan edukasi tentang pentingnya pengaturan konsumsi cairan latihan untuk mencapai status hidrasi yang baik saat latihan maupun pementasan. Untuk ketahanan fisik mahasiswi tari sebaiknya lebih meningkatkan intensitas untuk latihan olah tubuh karena dengan latihan olah tubuh yang teratur dapat meningkatkan ketahanan fisik untuk penari.

\section{DAFTAR PUSTAKA}

1. Robby, Hidayat. Wawasan Seni Tari Pengetahuan Praktis Bagi Guru Seni Tari. Malang: Fakultas Sastra Universitas Negeri Malang Jurusan Seni dan Desain.2005.Hal:1-30

2. Koutedakis Y, Jamurtas A. The dancer as a Performing Athlete Physiological Considerations. Sports Med 2004; 34 (10): 651-61

3. Bisri MH. Manfaat Olah Tubuh bagi Seorang Penari. Harmonia Jurnal Pengetahuan dan Pemikiran Seni 2001; 2:3.p.61-71.

4. Cesar A. Hincapié, DC, MHSc, Emily J. Morton, DC, FCCS(C), J. David Cassidy, PhD, DrMedSc. Musculoskeletal Injuries and Pain in Dancers: A Systematic Review. Arch Phys Med Rehabil 2008;89:1819-29.

5. Tarnopolsky, M.A., Gibala, M., Jeukendrup, A.E. \& Phillips, S.M. Nutritional needs of elite endurance athletes. Part 1 : Carbohydrate \& fluid requirement. European Journal of Sports Science, $2005: 5(1)$,

6. Angioi M, Metsios GS, Twitchett E, Koutedakis Y, Wyon. M. Association Between Selected Physical Fitness Parameters and Esthetic Competence in Contemporary Dancers. J Dance Med Sci. 2009;13(4):115-23.

7. Perhimpunan Dokter Gizi Medik Indonesia (PDGMI). Pentingnya Minum Air untuk Mencegah Dehidrasi. 2010. [cited 2014 April 22]. Available From URL: http://mediacatore.com/seminar/106/cegah_dehidr asi_ringan_dengan_pemeriksaan_urin_sendiri_(pu ri).html.

8. E, Fiona, Pelly.Gary j. Slater. Assessment of Hydration of Athletes.2011

9. Casa DJ. National Athletic Trainers' Association Position Statemen : Fluid Replacement for Atheletes. Journal of Athletic Training. 2000; 35(2): 212-24

10. Popkin BM, Kristen ED, Irwin HP. Water, Hydration and Health. Nutr Rev. 2010; 68(8): 43958

11. Whitmie S. Water, Electrolite And Acid Base Balance, In Nutrition and diet Therapy. USA: Saunders Company. 2004 [cited 2014 April 22

12. Armstrong, Lawrence. Assesing Hydration Status: The Elusive Gold Standard. Journal of the American College of Nutrition. 2007; 26 (14): 57584

13. Maffulli N, Chan KM, Macdonald R, Malina RM, Parker T. Sport Medicine for Specific Ages and Abilities. In: Wong MWN, To WWK, Chan KM. dance Medicine. Available from URL: https://www.us.elsevierhealth.com

14. Ronald H. Metoda Rehidrasi USATF sebagai Metode Alternatif Pemulihan Cairan Tubuh. Seminar Nasional. 2009.

15. Fink HH, Alan EM, Lisa AB. 2013. Practical Applications in Sport Nutrition $3^{\text {rd }}$ ed. Canada: Jones and Bartlett Publishers

16. Grandjean A. Water Requirements, Impinging Factors, and Recommended Intakes. World Health Organization. 2004

17. Sawka MN, Louise MB, E Randy E, Ronald JM, Scott JM, Nina SS. Exercise and Fluid Replacement. American College and Sport Medicine. 2007

18. Popkin BM, Kristen ED, Irwin HP. Water, Hydration and Health. Nutr Rev. 2010; 68(8): 43958.

19. American Dietetic Association. Position ofthe American Dietetic Association, Dietitiansof Canada, and the American College of Sports Medicine: Nutrition and athletic performance. J Am Diet Assoc. 2009.

20. Jeqiuer E, F Constant. Water as an essential nutrient: the Physiological basis of hydration. 
European Journal of Clinical Nutrition. (2010) 64, 115-123.

21. Khanna, G L, \& Manna, I. Supplementary effect of carbohydrate-electrolyte drink on sports performance, lactate removal \& cardiovascular response of athletes. Indian Journal of Medical Research, 2005

22. Yannakoulia M, Keramopoulos A, Tsakalakos N, Matalas AL. Body Composition in Dancer: The Bioelectrical Impedance Method. American College of Sports Medicine 2000; 288-234.

23. Singh R. Fluid Balance and Exercise Performance. Mal J Nutr 9(1): 53-74, 2003.

24. IPAQ Research Committee. Guidelines for Data Processing and Analysis of the International Physical Activity Questionnaire (IPAQ) - Short and Long Form. [serial online] 2005. Available from URL: HYPERLINK http://www.ipaq.ki.se

25. Gudmundsdottir SL, Flanders WD, Augestad LB. A Longitudinal Study of Physical Activity and Menstrual Cycle Characteristic in Healthy Norwegian Women-The Nord-Trondelag Health Study. Norsk Epidemiologi 2011; 20(2):163-71.

26. Merry,T.L, P.N.Ainslie and j.D. cotter Effects of aerobic fitness on hypohydration-induced physiological strain and exercise impairment. Acta Physiol 2010, 198, 179-90

27. Das B, Ghosh T, Gangopadhyay S. A . Comparative study of physical fitness index (PFI) and predicted maximum aerobic capacity (VO2max) among the different groups of female students in West Bengal India. Int J of Applied Sports Sci. 2010;22(1):1323.

28. Casa DJ. National Athletic Trainers' Association Position Statemen : Fluid Replacement for Atheletes. Journal of Athletic Training. 2000; 35(2): 212-24. Carvalho

29. Boschi V. Siervo M, D’Orsi P, margiotta N, Trapanese E, Basile F, et al. Body Composition, eating behavior, Food-Body Concerns and Eating disorder in Adolescent Girls. Ann Nutr Metab; 47: 284-293; 2003.

30. Jaihar Sidratulmuntaha, Djunaidi M.Dachlan, Yustini. Analisis Status Gizi dan Aktivitas Fisik dengan Ketahanan Fisik Siswa di Sekolah Polisi Negara (SPN)Batua Makassar Sulawesi Selatan. 2013.

31. Supriyanto. 2013. Pengaruh Latihan Lari Angkat Paha, Lompat Tepuk, Push-Up dengan Pola Circuit Training terhadap Peningkatan Kesegaran Jasmani (Studi pada Siswa Ekstrakulikuler Bola Basket SMP Negeri 2 Ketapang Kabupaten Sampang). Jurnal Prestasi Olahraga, 1 (1), hal. 1-20.

32. Koley, Syamal. Assocoation of cardio respiratory fitness, body composition and blood pressure in college population of arritsar. Punjab india. The jounal of Biological Anthropology.1(1).2007

33. Adiwinanto, Wahyu. Pengaruh Intervensi Olahraga di Sekolah terhadap Masa Tubuh dan tingkat Kesegaran Jasmani Kardiorespirasi pada Remaja
Obesitas, Semarang: Tesis Program Pascasarjana Program Pendidikan Dokter Spesialis Ilmu Kesehatan Anak Fakultas Kedokteran Universitas Diponegoro. 2008 